\title{
Host Plant Resistance Against Tomato spotted wilt virus in Peanut (Arachis hypogaea) and Its Impact on Susceptibility to the Virus, Virus Population Genetics, and Vector Feeding Behavior and Survival
}

\author{
Sivamani Sundaraj, Rajagopalbabu Srinivasan, Albert K. Culbreath, David G. Riley, and Hanu R. Pappu
}

First, second, and fourth authors: Department of Entomology, and third author: Department of Plant Pathology, University of Georgia, Tifton 31793; and fifth author: Department of Plant Pathology, Washington State University, Pullman 99164. Accepted for publication 30 August 2013.

\begin{abstract}
Sundaraj, S., Srinivasan, R., Culbreath, A. K., Riley, D. G., and Pappu, H. R. 2014. Host plant resistance against Tomato spotted wilt virus in peanut (Arachis hypogaea) and its impact on susceptibility to the virus, virus population genetics, and vector feeding behavior and survival. Phytopathology 104:202-210.

Tomato spotted wilt virus (TSWV) severely affects peanut production in the southeastern United States. Breeding efforts over the last three decades resulted in the release of numerous peanut genotypes with field resistance to TSWV. The degree of field resistance in these genotypes has steadily increased over time, with recently released genotypes exhibiting a higher degree of field resistance than older genotypes. However, most new genotypes have never been evaluated in the greenhouse or laboratory against TSWV or thrips, and the mechanism of resistance is unknown. In this study, TSWV-resistant and -susceptible genotypes were subjected to

Parsimony and principal component analyses of $N$ gene nucleotide sequences revealed inconsistent differences between virus isolates collected from resistant and susceptible genotypes and between old (collected in 1998) and new (2010) isolates. Amino acid sequence analyses indicated consistent differences between old and new isolates. In addition, we found evidence for overabundance of nonsynonymous substitutions. However, there was no evidence for positive selection. Purifying selection, population expansion, and differentiation seem to have influenced the TSWV populations temporally rather than positive selection induced by host resistance. Choice and no-choice tests indicated that resistant and susceptible genotypes differentially affected thrips feeding and survival. Thrips feeding and survival were suppressed on some resistant genotypes compared with susceptible genotypes. These findings reveal how TSWV resistance in peanut could influence evolution, epidemiology, and management of TSWV.
\end{abstract} TSWV mechanical inoculation. The incidence of TSWV infection was 71.7 to $87.2 \%$. Estimation of TSWV nucleocapsid $(N)$ gene copies did not reveal significant differences between resistant and susceptible genotypes.
Additional keywords: Frankliniella fusca, tobacco thrips, Tospovirus.
Tomato spotted wilt virus (TSWV) (family Bunyaviridae, genus Tospovirus) is one of the most important pathogens affecting peanut production in the southeastern United States $(12,15,22)$. TSWV is transmitted by at least 10 species of thrips (Thysanoptera: Thripidae) in a persistent and propagative manner $(47,50$, 65). In all, 2 of the 10 species, Frankliniella fusca Hinds (tobacco thrips) and $F$. occidentalis Pergande (western flower thrips), are found on peanut in the southeastern United States $(50,62,63)$. Of the two species, $F$. fusca is considered to be a more important vector of TSWV on peanut. F. occidentalis does not reproduce as efficiently as $F$. fusca on peanut foliage $(62,63)$. Early-season (soon after planting) thrips foliar feeding and colonization are critical for TSWV spread (15).

At the onset of TSWV incidence in the southeastern United States in the 1980s, genotypes predominantly grown at that time such as 'Florunner' were extremely susceptible to TSWV, resulting in severe yield losses $(12,15,16)$. Another genotype, 'Southern Runner', was found to have low levels of field resistance to TSWV but it was planted on only a small percentage of the peanut production area $(16,23)$. Subsequently, intensive screening efforts led to the identification of several sources of resistance and

Corresponding author: R. Srinivasan; E-mail address: babusri@uga.edu

* The $\boldsymbol{e}$-Xtra logo stands for "electronic extra" and indicates that Figure 1 appears in color online.

http://dx.doi.org/10.1094/PHYTO-04-13-0107-R

(c) 2014 The American Phytopathological Society release of genotypes that exhibited field resistance such as 'Georgia Green', 'Georgia Browne', 'Tamrun 98', and 'Florida MDR 98' $(6,7,14,19,56)$. In this article, these genotypes will be referred to as first-generation TSWV-resistant peanut genotypes. Among these genotypes, Georgia Green was the predominant one. It was grown on $>80 \%$ of the acreage by 1999 (15). Successive breeding efforts led to the release of a suite of TSWV-resistant peanut genotypes such as 'Georgia Greener', 'Georgia-06G', 'Georganic', 'Georgia-02C', and 'Tifguard'. These genotypes have much higher levels of field resistance to TSWV than the first-generation TSWV-resistant genotypes $(8-10,25,26)$. These genotypes will be referred to as second-generation TSWV-resistant peanut genotypes. Most recently, third-generation genotypes with greater levels of TSWV resistance than second-generation TSWV-resistant genotypes (such as 'Georgia-10T') were developed but they are not widely available to growers yet (11).

Peanut genotypes displaying field resistance have been used as the most important management tactic against TSWV in the southeastern United States for approximately two decades. Dominant genes such as $S w-5$ and $T s w$ are known to confer resistance to TSWV in tomato (Solanum lycopersicon L.) and pepper (Capsicum annuum L.), respectively, by triggering a hypersensitive reaction (HR) $(3-5,43,53,57)$. However, no such genes or HR have been associated with field resistance in peanut. Field resistance in peanut is typically characterized by a reduced number of symptomatic plants and higher yields than TSWV-susceptible genotypes under TSWV pressure (15). The mechanism governing TSWV field resistance in peanut is unknown. It is not clear 
whether varying degrees of host plant resistance exerted any selection pressure on the virus itself. Exertion of such selection pressure could reshape the population structure of the virus and result in the development of resistance-breaking strains, which would reduce the usefulness of resistant genotypes. Resistancebreaking strains of TSWV have been observed in multiple locations and crops $(36,43,51,52)$. Such strains have not been observed in peanut.

Unlike solanaceous crops such as pepper in which thrips resistance has been identified $(41,42)$, no resistance to thrips has been observed in peanut genotypes grown in the United States. Thus far, low incidence of spotted wilt in second-generation TSWV-resistant genotypes is not believed to be due to resistance against the vector but due to field resistance against the virus alone (12-15). However, these genotypes have only been evaluated for thrips feeding-induced damage under field conditions. No research has been conducted on thrips resistance under greenhouse or laboratory conditions.

In this study, we qualitatively and quantitatively evaluated the response of second-generation TSWV-resistant peanut genotypes following mechanical inoculation with TSWV. We assessed whether the continuous usage of TSWV-resistant genotypes over two decades exerted any selection pressure on the virus itself, or whether other evolutionary factors influenced the population genetic structure of TSWV in Georgia. The effects of these genotypes on thrips feeding damage and thrips survival also were assessed.

\section{MATERIALS AND METHODS}

Maintenance of TSWV-infected plants. Foliage from peanut plants exhibiting TSWV symptoms such as mosaic and concentric ring spots were collected from a peanut field in the Black Shank Farm at the Coastal Plain Experiment Station, The University of Georgia, Tifton. TSWV infection status was confirmed by doubleantibody sandwich enzyme-linked immunosorbent assay (DASELISA) using TSWV-specific antiserum (Agdia, Elkhart, IN). The virus was maintained in Nicotiana tabacum L. through mechanical inoculations (described below). The infection status of tobacco plants was verified by DAS-ELISA. TSWV-infected tobacco leaves were used as the inoculum source for performing mechanical inoculations on various peanut genotypes.

Mechanical inoculation. Four second-generation TSWV-resistant peanut genotypes (Georgia Greener, Georganic, Tifguard, and Georgia-02C) and a TSWV-susceptible genotype (Georgia Green) were mechanically inoculated $\approx 1$ week after planting as described by Mandal et al. (39). Although Georgia Green was more resistant to TSWV than other peanut genotypes prior to its introduction, it is much more susceptible to TSWV than second- and thirdgeneration TSWV-resistant genotypes. Because of this and the lack of seed availability of most of the older cultivars, Georgia Green is commonly used as a susceptible standard in breeding line evaluations. Hence, Georgia Green was considered a susceptible genotype in our experiments. In all, 15 or 20 plants of each genotype were inoculated per experiment, which were triplicated. Each plant was considered to be a replicate for a total of 50 plants for all three repeats of the experiment.

Leaves from symptomatic tobacco plants infected with TSWV were ground in a 1:10 ratio (wt/vol) in $0.1 \mathrm{M}$ phosphate buffer, pH 7.0, containing $0.2 \%$ sodium sulfite, $0.01 \mathrm{M}$ mercaptoethanol, Celite 545 (Acros Organics, Geel, Belgium), and carborundum (320 grit; Fisher Scientific, Fair Lawn, NJ) at $0.01 \mathrm{~g} / \mathrm{ml}$. The extract was then rubbed onto leaves of peanut plants that had been previously dusted with carborundum. Inoculated plants were placed in thrips-proof cages at 25 to $30^{\circ} \mathrm{C}$ and 80 to $90 \%$ relative humidity with a photoperiod of $14 \mathrm{~h}$ of light and $10 \mathrm{~h}$ of darkness in the greenhouse. Control plants were inoculated using healthy tobacco leaves. TSWV infection status of inoculated plants was tested by DAS-ELISA 2 to 3 weeks postinoculation. Experiment was considered as the blocking variable, and data from all repeats of the experiment were pooled. TSWV infection status was treated as a binomial response (positive or negative). Differences in incidence of TSWV infection among peanut genotypes were estimated using PROC GENMOD with the logit function in SAS at $P=0.05$ (SAS Enterprise 4.2, Cary, NC).

TSWV nucleocapsid gene copies in peanut genotypes. Viral copies in peanut genotypes were estimated by quantitative reverse-transcriptase polymerase chain reaction (qRT-PCR). In all, 10 symptomatic ELISA-positive plants from each peanut genotype were evaluated by qRT-PCR using a nucleocapsid $(N)$ genespecific primer pair that amplified a 139-bp fragment; that is, TSWV-NPF (5' GCTTCCCACCCTTTGATTC 3') and TSWVNPR (5' ATAGCCAAGACAACACTGATC 3') (54). Total RNA was extracted from ELISA positive plant tissue using an RNeasy Plant Mini Kit (Qiagen, Valencia, CA) following the manufacturer's instructions. The cDNA was prepared using the GoScript Reverse Transcription System (Promega Corp., Madison, WI). The qRT-PCR was conducted using Realplex Mastercycler (Eppendorf, Hamburg, Germany) with a reaction volume of $25 \mu \mathrm{l}$, containing $1.0 \mu \mathrm{l}$ of the first-strand cDNA, $0.5 \mu \mathrm{M}$ each of the primers, $12.5 \mu \mathrm{l}$ of GoTaq qPCR Master Mix (Promega Corp.), and $10.5 \mu \mathrm{l}$ of nuclease-free water. PCR was initiated with a denaturation step at $95^{\circ} \mathrm{C}$ for 2 min followed by 40 cycles of denaturation at $95^{\circ} \mathrm{C}$ for $15 \mathrm{~s}$, annealing at $55^{\circ} \mathrm{C}$ for $60 \mathrm{~s}$, and extension at $72^{\circ} \mathrm{C}$ for $20 \mathrm{~s}$. Immediately after the final PCR cycle, a melting-curve analysis was done to determine the specificity of the reaction by incubating the reaction at $95^{\circ} \mathrm{C}$ for $15 \mathrm{~s}$ and annealing at $60^{\circ} \mathrm{C}$ for $15 \mathrm{~s}$, and then increasing the temperature by $0.5^{\circ} \mathrm{C} / \mathrm{min}$ for $20 \mathrm{~min}$. All samples were run in duplicates.

Plasmids with $N$ gene inserts were used as external standards. RT-PCR with TSWV $N$-gene-specific primers (described below) yielded $\approx 800$-bp amplicons that were used for cloning. Plasmids with $N$ gene inserts were obtained by TOPO cloning following the manufacturer's recommendations (Invitrogen, Carlsbad, CA). Plasmids were purified using a GeneJet, Plasmid Miniprep Kit (Fermentas Inc., Glen Burnie, MD). Purified plasmids were digested with HindIII. Restriction digestion and the presence of the insert were confirmed following standard procedures. Linearized plasmids were quantified using Nanodrop (Thermo Scientific, Wilmington, DE). Copy numbers were estimated using a formula based on the assumption that the average weight of a base pair is $650 \mathrm{Da}$ [number of copies $=\left(\right.$ amount $\left.\times 6.022 \times 10^{23}\right) /$ (length $\left.\times 1 \times 10^{9} \times 650\right)$ ]. Plasmids with inserts were serially diluted $\left(6.4 \times 10^{7}\right.$ copies to 6.4 copies $)$ and used as standards. For each standard, threshold cycle was calculated and a standard curve was generated. Number of $N$ gene copies in leaf tissue samples was estimated by using the standard curve.

Data were analyzed by generalized mixed linear models using PROC GLIMMIX in SAS to identify differences in $N$ gene copies among genotypes. Treatments (genotypes) were considered as fixed effects and replications were considered as random effects. Least square means were used to identify differences in $N$ gene copies among genotypes at $P=0.05$.

Characterization and phylogenetic analysis of TSWV isolates from TSWV-resistant and -susceptible peanut genotypes. During summer 2010, 78 TSWV isolates were collected from TSWV-resistant and -susceptible peanut genotypes from 10 counties (Berrien, Burke, Coffee, Colquitt, Decatur, Mitchell, Sumter, Terell, Tift, and Toombs) in Georgia. Three isolates, one each from TSWV-susceptible pepper, tobacco, and tomato, were also collected from Tift County. Leaf samples showing symptoms suggestive of TSWV infection were initially tested with DASELISA. Total RNA was extracted from ELISA-positive foliar samples of resistant and susceptible peanut genotypes as described previously. RT-PCR was performed by a OneStep RTPCR kit (Qiagen). The reaction volume was $50 \mu \mathrm{l}$, which included 
$0.6 \mu \mathrm{M}$ each forward and reverse primer (32), $2 \mu \mathrm{l}$ of one-step RTPCR enzyme mix, $10 \mu$ of RT-PCR buffer, $10 \mu \mathrm{l}$ of Q solution, and $400 \mu \mathrm{M}$ each dNTP. Reverse transcription was performed in an automated thermal cycler (Eppendorf) programmed at $50^{\circ} \mathrm{C}$ for $30 \mathrm{~min}$. Initial PCR activation was conducted at $95^{\circ} \mathrm{C}$ for 15 min; followed by 35 cycles at $94^{\circ} \mathrm{C}$ for $1 \mathrm{~min}, 56^{\circ} \mathrm{C}$ for $45 \mathrm{~s}$, and $72^{\circ} \mathrm{C}$ for $1 \mathrm{~min}$; and a final extension step at $72^{\circ} \mathrm{C}$ for $10 \mathrm{~min}$. The amplicons were analyzed by electrophoresis on $1 \%$ agarose gel. The PCR products were purified using the QIA-quick PCR purification kit (Qiagen) following the manufacturer's recommendations and directly sequenced in both directions. Sequencing was performed at the Georgia Genomics Facility (Athens, GA).

$N$ gene sequences of 81 isolates collected in 2010 (GenBank accession numbers HQ406903 to HQ406984) and 9 isolates collected in 1998 (AF048714 to AF048716 and AF064469 to AF64474) were used for phylogenetic analysis. The nine isolates were collected from peanut and solanaceous crops from Tift County (48). $N$ gene nucleotide and translated amino acid sequences were aligned using CLUSTAL $X$ after setting the parameters for pairwise and multiple alignment (24). The aligned sequences were subjected to maximum parsimony analysis in PAUP 4.0 (58). Principal component analysis was conducted by subjecting PAUP output to the Markovian evolution model with Brownian default in Mesquite 2.75 (38). Haplotype analysis was conducted using DnaSP v5 (37) to identify the presence of variants with single-nucleotide polymorphisms within populations, their diversity, and variance associated with diversity.

Identification of selection. Selection among TSWV isolates was assessed by evaluating the synonymous (S) and nonsynonymous $(\mathrm{N})$ substitutions for each codon using the HyPhy package in MEGA $5(34,61)$. The nonsynonymous substitutions per site $(\mathrm{dN})$ and synonymous substitutions per site $(\mathrm{dS})$ were obtained by using the joint likelihood maximum reconstructions of ancestral states under a Muse-Gaut model of codon substitution and Tamura-Nei model of nucleotide substitution $(45,60)$. For sites where $\mathrm{dN}>\mathrm{dS}$, the selection was assumed to be positive.

Tests of neutrality in population. Tajima's D (59) was used to assess the neutrality in the population by estimating population mutation rate $(\theta)$, identifying the number of segregating or polymorphic sites, and assessing the average number of nucleotide differences in DnaSP. Fu and Li's D and F statistics (21) were calculated by estimating the differences between number of singletons (mutations appearing only once among sequences) and average nucleotide differences between sequence pairs. Fu's F statistic (20) was calculated by assuming that a mutation could occur at infinite sites using DnaSP. It is a sensitive indicator of population expansion or genetic hitchhiking.

Population differentiation tests. Haplotype-based statistics Hs and Hst (29) and nucleotide-based statistics Ks, Kst, and Snn $(28,29)$ were used to identify genetic differentiation within populations using DnaSP. Hudson's Fst (31) was used to examine the extent of genetic differentiation or gene flow between populations or subgroups.

Tests to detect recombination. DnaSP was used to estimate the recombination parameter $\mathrm{R}(=4 \mathrm{NR})$, where $\mathrm{N}$ represents the population size and $\mathrm{r}$ is the recombination rate per sequence (27). The parameter was obtained by evaluating the variance of the average number of nucleotide differences between sequence pairs. The minimum number of recombination events (Rm) (30) was calculated using coalescent simulation with 1,000 permutations by incorporating the observed $\mathrm{Rm}$ value, recombination level, and $\theta$ at a $95 \%$ confidence level.

Thrips feeding damage and survival. A population of $F$. fusca collected from a peanut field at the Belflower Farm, Coastal Plain Experiment Station, The University of Georgia, Tifton was maintained on healthy peanut leaves in modified Munger cells (44) in a growth chamber (Thermo Scientific, Dubuque, IA) at 25 to $30^{\circ} \mathrm{C}$ with a photoperiod of $14 \mathrm{~h}$ of light and $10 \mathrm{~h}$ of darkness.
Thrips feeding damage and survival were evaluated by choice and no-choice tests. For choice tests, all five peanut genotypes, $\approx 1$ week old, were randomly placed in a thrips-proof cage $\left(47.5 \mathrm{~cm}^{3}\right.$ ) (Megaview Science Co., Taichung, Taiwan). In all, 50 female $F$. fusca reared on healthy peanut were released into each cage at 10 thrips/plant. Pine pollen was dusted on the test plants before thrips release to support the initial thrips development (2). Every alternative day, the feeding injuries were recorded and rated on an arbitrary scale ranging from zero (no damage) to three (severe damage) for up to 30 days. Feeding damage index (FDI) was calculated based on a formula proposed by Maris et al. (42) with slight modifications: FDI $=$ (number of leaflets with feeding damage/total number of leaflets in a plant $) \times$ intensity of feeding scars.

In addition, the number of surviving thrips larvae and adults were counted every alternate day for up to 30 days. This experiment had four replicates and was triplicated with four to five replicates each time, such that there was a total of 13 replicates for all repeats of the experiment. To compare statistical differences in feeding damage and thrips survival, three representative time intervals of 10,20 , and 30 days after thrips release were selected.

Experiment was considered as the blocking variable, and data from all repeats of the experiment were pooled. Treatments (genotypes) were considered as fixed effects and replications were considered as random effects. Analysis of variance was performed by using PROC GLM in SAS. The same thrips population was observed throughout the sampling period. The observations over time were treated as repeated measures. The statistical significance of differences between treatments was estimated using least squares means at $P=0.05$.

In a no-choice test, five seedlings from the same peanut cultivar were placed in a thrips-proof cage, and 50 female $F$. fusca were released in each cage at 10 thrips/plant. Every alternate day, feeding damage and number of larvae and adult thrips on each plant was recorded for up to 30 days, as described above. The damage index was calculated as previously described. This experiment was triplicated with 15 replicates for all repeats of the experiment. Statistical analyses were performed as described for choice tests.

\section{RESULTS}

Incidence of TSWV infection and $N$ gene copies in TSWVresistant and -susceptible genotypes. Mechanically inoculated susceptible and resistant peanut genotypes developed typical TSWV-induced symptoms 2 weeks postinoculation (Fig. 1). Symptoms included mosaic, mottling, and concentric ringspots. All five peanut genotypes were also systemically infected with TSWV. None of the uninoculated plants exhibited symptoms, and their foliar samples did not test positive by ELISA. The incidence of TSWV infection among TSWV-resistant and -susceptible genotypes varied with the repeats of the experiment ( $\mathrm{df}=2,247$; $\left.\chi^{2}=21.19 ; P<0.0001\right)$. TSWV infection percentages in Georgia Green and Georgia-02C were $87.22 \pm 6.93$ (mean \pm standard error) and 87.22 \pm 10.39 , respectively. The infection percentages were less in Georgia Greener (80.00 $\pm 10.19 \%)$, Georganic $(71.67 \pm 22.53 \%)$, and Tifguard $(78.33 \pm 8.56 \%)$ than in Georgia Green and Georgia-02C. Overall, differences in the incidence of TSWV infection among peanut genotypes were not statistically significant $\left(\mathrm{df}=4,245 ; \chi^{2}=8.06 ; P=0.0895\right)$. Ten plants of each genotype that tested positive by ELISA alone were evaluated by qRT-PCR. The $N$ gene copy numbers did not vary among genotypes $(\mathrm{df}=4,45 ; F=0.91 ; P=0.4669)$ (Fig. 2$)$.

Phylogenetic and haplotype analyses. Maximum parsimony analysis was conducted with both nucleotide and amino acid sequences. Analysis of nucleotide sequences indicated that 667 characters were constant, 68 characters were parsimony uninformative, and 42 characters were parsimony informative. The 
homoplasy index, consistency index, and retention index were $0.5891,0.4109$, and 0.2636, respectively. Principal component analysis indicated no clear clustering differences between $N$ gene sequences from old and new sequences or between TSWV-susceptible and -resistant $N$ gene sequences. Analysis of amino acid sequences indicated that 243 characters were constant, 11 characters were parsimony uninformative, and 4 characters were parsimony informative. The homoplasy index, consistency index, and retention index were $0.4483,0.5517$, and 0.5806 , respectively. A two-dimensional principal component analysis plot indicated that the sequences grouped in two clusters (Fig. 3). Amino acid sequences of the new isolates and old isolates were found in separate clusters. Careful examination of the sequences indicated that there was at least one consistent amino acid substitution between old and new isolates, with cysteine at position 222 in the latter isolates instead of serine. Haplotype analysis indicated that there was high haplotype diversity and low nucleotide diversity overall and among all subgroups (Table 1). Overall, there were 81 haplotypes. Among the subgroups, the number of haplotypes varied from 7 to 74 . However, the numbers were proportional to their sample sizes.

Selection, neutrality, and recombination. Tests for selection indicated that, in at least seven codons, the test statistic $\mathrm{dN}-\mathrm{dS}$ was positive, indicating overabundance of $\mathrm{dN}$ (Table 2). However, these substitutions were not significant enough to reject the theory of neutral mutation, indicating the absence of positive selection. Tajima's test of neutrality indicated that the D values for the overall population as well as all subgroups were negative, sug- gesting that purifying selection or population expansion could have influenced the observed population diversity (Table 3). Fu and Li's D and F statistics were negative, also suggesting the presence of purifying selection or population expansion (Table 3 ). However, a negative Fu's F provided a stronger evidence for recent population expansion (Table 3).

Hudson's haplotype statistics Hs and Hst and their associated $\chi^{2}$ statistics indicated no evidence of differentiation between old

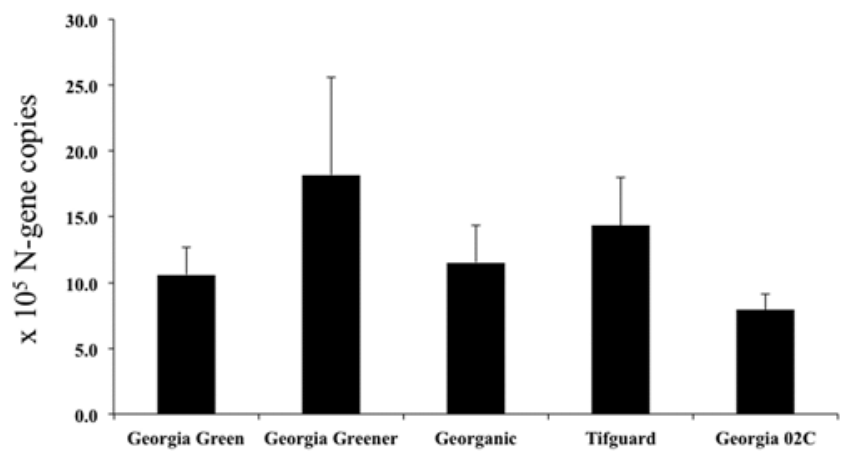

Fig. 2. Nucleocapsid $(N)$ gene copies of Tomato spotted wilt virus (TSWV) from TSWV-resistant and -susceptible peanut genotypes following mechanical inoculation. Copy numbers were determined by using plasmids with $N$ gene inserts as standards in quantitative reverse-transcriptase polymerase chain reaction 3 weeks after mechanical inoculation. Bars indicate means \pm standard errors.

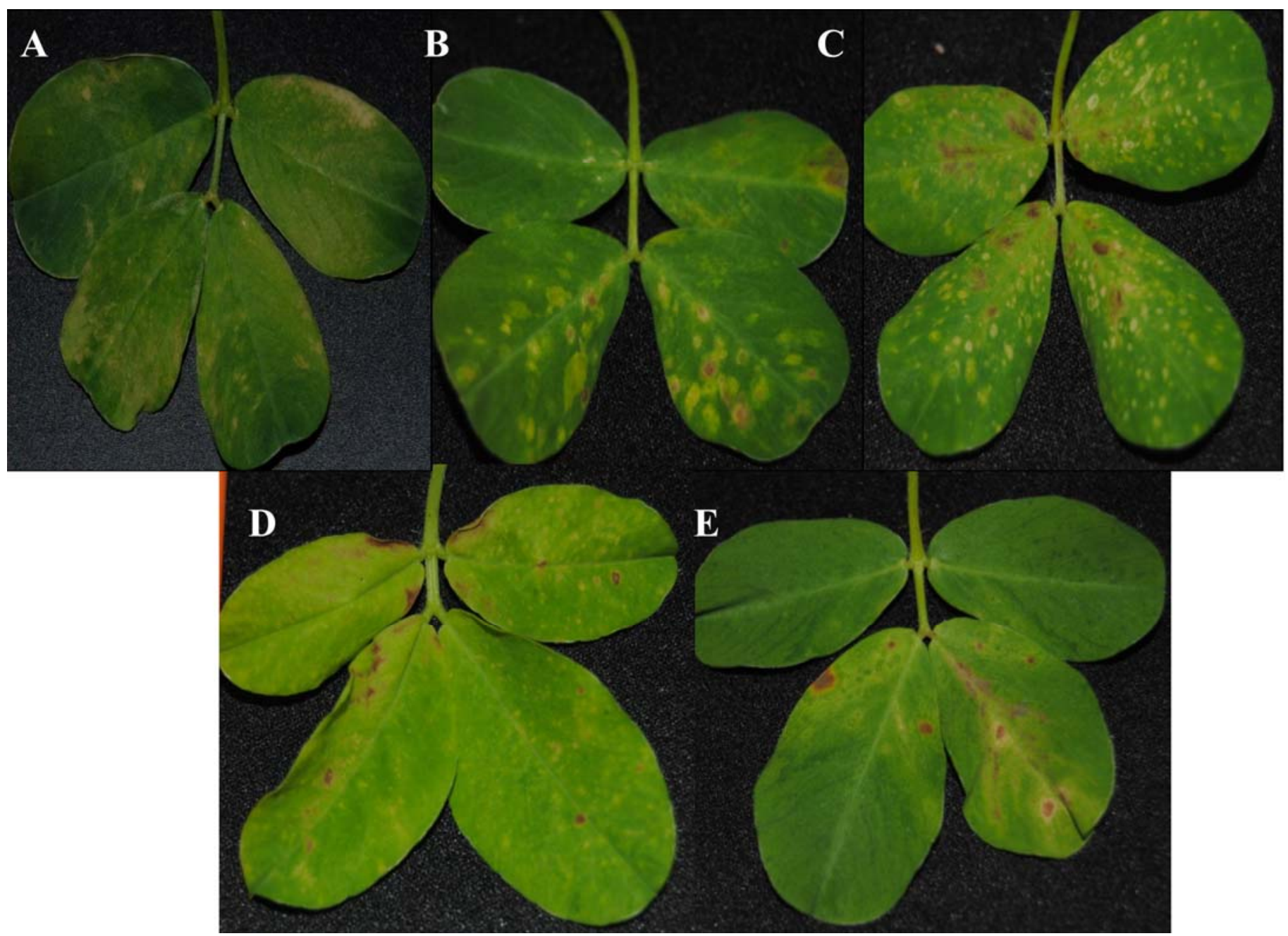

Fig. 1. Foliar symptoms on Tomato spotted wilt virus (TSWV)-resistant and -susceptible peanut genotypes following mechanical inoculation of TSWV: A, Georgia Green; B, Georgia Greener; C, Georganic; D, Tifguard; and E, Georgia-02C. 
and new subgroups or between isolate subgroups from TSWVsusceptible and -resistant genotypes. In contrast, Hudson's nucleotide statistics Kt, Ks, and Kst provided evidence for differentiation between old and new isolates but not between isolates from TSWV-resistant and -susceptible genotypes (Table 4). Kst value close to zero indicated no differentiation. Similarly, Hudson's Snn indicated evidence for differentiation between the old and new subgroups but not between susceptible and resistant subgroups (Table 4). Hudson's Fst also indicated the presence of interpopulation diversity between old and new subgroups but not between susceptible and resistant subgroups (Table 4).

Recombination rate per gene, overall, was 22.80 . The rate was 1.48 times more in new isolates (30.49) when compared with old isolates (20.59). However, there were no significant differences between isolates collected from susceptible (25.19) and resistant genotypes (23.29). The recombination rates between adjacent sites did not vary significantly among subgroups. The observed and simulated minimum number of recombination events was greater in new isolates (12.00 and 5.05) than in old isolates (2.00 and 2.09). Also, they were greater in isolates from resistant genotypes (12.00 and 4.84) than from susceptible genotypes (3.00 and 2.45). In general, the simulated numbers of minimum recombination events were lower than observed events for all subgroups except old isolates.

Thrips feeding damage and survival. Feeding induced damage was observed in all genotypes in choice tests. Feeding damage index did not vary with the repeats of the experiment at 10 days ( $\mathrm{df}=2,10 ; F=2.50 ; P=0.0913$ ). However, the damage index varied with repeats of the experiment at 20 days ( $\mathrm{df}=2,10$; $F=25.28 ; P<0.0001)$ and 30 days $(\mathrm{df}=2,10 ; F=18.51 ; P<$ $0.0001)$ post thrips release. In some instances, more feeding injuries were recorded in Georgia-02C than in all other genotypes tested. Tifguard and Georganic had the least amount of feeding injuries (Table 5). The number of thrips found on various genotypes varied with experiments at $10(\mathrm{df}=2,10 ; F=3.39$; $P=0.0406), 20(\mathrm{df}=2,10 ; F=4.11 ; P=0.0214)$, and $30(\mathrm{df}=2$, $10 ; F=18.05 ; P<0.0001)$ days post thrips release. The number of thrips observed on all genotypes varied over time. Their populations mirrored the feeding damage indices. The number of thrips observed on Tifguard and Georganic were significantly lower than on all other genotypes included in this study (Table 6), wherein the number of thrips did not vary between Tifguard and Georganic at all time intervals tested. Also, no differences were observed among Georgia Green, Georgia-02C, and Georgia Greener (Table 6).

Feeding damage observed varied with genotypes in the nochoice test. The feeding damage severity varied with experiments at $10(\mathrm{df}=2,12 ; F=16.77 ; P<0.0001), 20(\mathrm{df}=2,12 ; F=$ $18.25 ; P<0.0001)$, and 30 ( $\mathrm{df}=2,12 ; F=19.59 ; P<0.0001)$ days post thrips release. At all time intervals, Tifguard and Georganic had the least amount of feeding damage when compared with Georgia Green, Georgia Greener, and Georgia-02C (Table $7)$. Similar to the choice test, the number of thrips on genotypes varied with experiments at $10(\mathrm{df}=2,12 ; F=21.04 ; P<0.0001)$

TABLE 1. Summary of haplotype analysis

\begin{tabular}{lcccc}
\hline Subgroup & $\pi^{\mathrm{w}}$ & $\begin{array}{c}\text { Number of } \\
\text { haplotypes }^{\mathrm{x}}\end{array}$ & $\begin{array}{c}\text { Haplotype } \\
\text { diversity }^{\mathrm{y}}\end{array}$ & Variance $^{\mathrm{z}}$ \\
\hline Overall & 0.0083 & 81 & 0.992 & 0.0000 \\
Old & 0.0102 & 7 & 0.944 & 0.0049 \\
New & 0.0075 & 74 & 0.991 & 0.0004 \\
Susceptible & 0.0098 & 10 & 1.000 & -0.0020 \\
Resistant & 0.0098 & 64 & 0.988 & -0.0000 \\
\hline
\end{tabular}

${ }^{\text {w }}$ Nucleotide diversity.

${ }^{x}$ Number of haplotypes in a population.

${ }^{\mathrm{y}}$ Haplotype diversity (the uniqueness of haplotypes in a population).

z Variance of haplotype diversity.

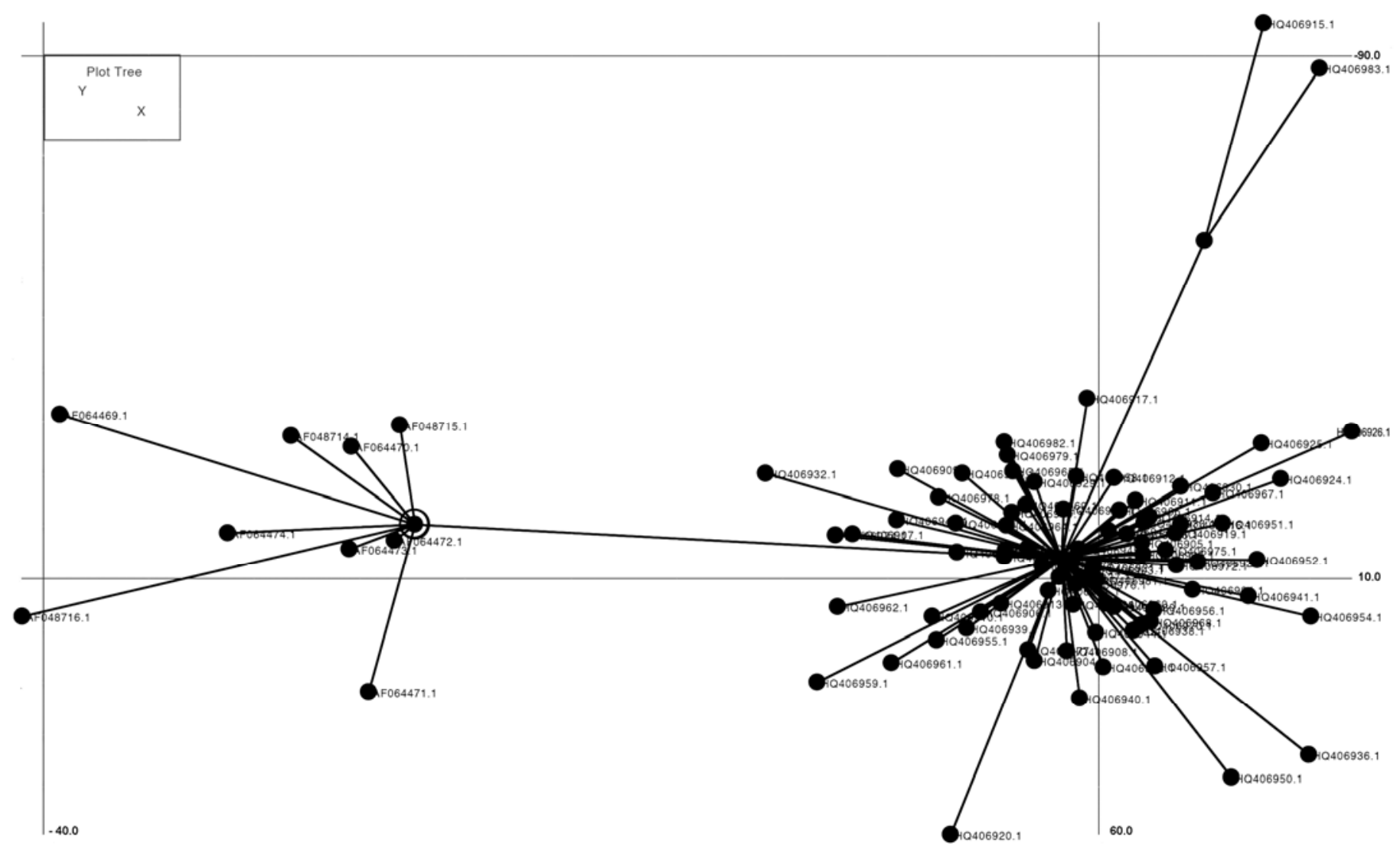

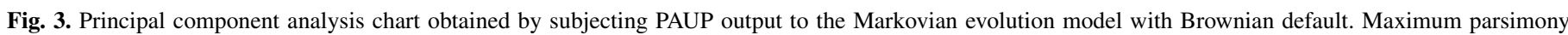
analysis with 2,000 bootstrap replicates was conducted using Tomato spotted wilt virus nucleocapsid gene amino acid sequences. 
and $30(\mathrm{df}=2,12 ; F=15.87 ; P<0.0001)$ days but not at $20(\mathrm{df}=$ 2,$12 ; F=0.20 ; P=0.8152$ ) days. Tifguard and Georganic had fewer thrips than the other three genotypes (Table 8). Tifguard, in particular, had consistently fewer thrips than all other genotypes. However, in all occasions, the numbers of thrips found on Tifguard and Georganic were not statistically different.

\section{DISCUSSION}

Genotypes of tomato and pepper with dominant genes $S w-5$ and $T s w$, respectively, confer resistance to TSWV by exhibiting a HR $(5,43,57)$. Such a HR results in rapid death of cells at or around virus entry sites, thereby confining viral infections to lesions and their adjacent cells. This phenomenon is known to restrict the systemic movement of the virus. In contrast, no such genes have been associated with field resistance to TSWV in peanut, and the mechanisms influencing field resistance in peanut remain unknown. Mechanical inoculation of first-generation TSWV-resistant genotypes also did not provide evidence of presence of HR (40). The second-generation TSWV-resistant genotypes, which are believed to possess a higher magnitude of

TABLE 2. Summary of codon positions with amino acid substitutions and probabilities for evaluating positive selection

\begin{tabular}{lccc}
\hline Codon position $^{\mathrm{w}}$ & $\mathrm{dN}-\mathrm{dS}^{\mathrm{x}}$ & Amino $^{\mathrm{acid}}$ changes & $P^{\mathrm{y}}$ \\
\hline 10 & 0.9804 & $\mathrm{~K} \rightarrow \mathrm{I}$ & 0.4624 \\
18 & 0.4999 & $\mathrm{~S} \rightarrow \mathrm{N}$ & 0.6669 \\
19 & 0.4893 & $\mathrm{G} \rightarrow \mathrm{S}$ & 0.7143 \\
36 & 0.5000 & $\mathrm{~T} \rightarrow \mathrm{I}$ & 0.6667 \\
40 & 1.6002 & $\mathrm{~N} \rightarrow \mathrm{T}$ & 0.3494 \\
175 & 0.5211 & $\mathrm{~K} \rightarrow \mathrm{R}$ & 0.6704 \\
222 & 0.4465 & $\mathrm{C} \rightarrow \mathrm{S}$ & 0.6117 \\
253 & 0.4898 & $\mathrm{~K} \rightarrow \mathrm{N}$ & 0.7134 \\
\hline
\end{tabular}

${ }^{\mathrm{w}}$ Codon positions where Nonsynonymous substitutions $(\mathrm{dN})>$ synonymous substitutions $(\mathrm{dS})$.

${ }^{\mathrm{x}} \mathrm{dN}$ and $\mathrm{dS}$ were obtained by using the joint likelihood maximum reconstructions of ancestral states. A positive value for test statistic $\mathrm{dN}-\mathrm{dS}$ indicated an overabundance of $\mathrm{dN}$.

${ }^{y}$ Substitutions resulting in amino acid changes.

${ }^{\mathrm{z}}$ Probability values for substitutions; substitutions with a probability value of $<0.05$ alone were considered significant enough to influence positive selection.

TABLE 3. Summary of test statistics for evaluating neutrality in populations

\begin{tabular}{lcccr}
\hline Subgroup & Tajima's D $^{\mathrm{w}}$ & Fu \& Li's D $^{\mathrm{x}}$ & Fu \& Li's Fy & \multicolumn{1}{c}{ Fu's F $^{\mathrm{z}}$} \\
\hline Overall & -2.3587 & -5.1900 & -4.8060 & -122.857 \\
Old & -1.0002 & -1.1162 & -1.2202 & -0.201 \\
New & -2.4107 & -5.3155 & -4.9499 & -115.544 \\
Susceptible & -1.11123 & -1.0124 & -1.1700 & -4.341 \\
Resistant & -2.3192 & -4.4996 & -4.3291 & -99.899 \\
\hline
\end{tabular}

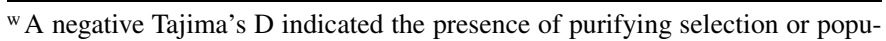
lation expansion.

${ }^{x}$ A negative Fu and Li's D supported purifying selection or population expansion.

y A negative $\mathrm{Fu}$ and Li's $\mathrm{F}$ supported purifying selection or population expansion.

${ }^{z}$ A negative Fu's F supported population expansion. resistance than the first-generation genotypes, have never been evaluated under controlled greenhouse conditions. Mechanical inoculation of TSWV in this study clearly suggested that the infection spreads to uninoculated parts, thereby confirming a lack of HR. The inoculated plants exhibited typical TSWV symptoms on both TSWV-resistant and -susceptible genotypes. Also, qRTPCR revealed no differences in $N$ gene copy numbers between resistant and susceptible genotypes. This indicated that the virus replication was not restricted in genotypes that are known to display a higher magnitude of field resistance to TSWV. These results are contrary to our recently obtained results with thripsmediated inoculations, where TSWV incidence and $N$ gene copy numbers were lower in some genotypes that displayed field resistance to TSWV (55). The mode of inoculation utilized and perhaps the load of virus delivered to the host plant in this study could have contributed to the differences observed. An earlier study also observed reduced incidences of TSWV infection in thrips-inoculated tomato plants when compared with mechanically inoculated plants (35).

TABLE 5. Feeding damage induced by thrips on Tomato spotted wilt virus (TSWV)-resistant and -susceptible peanut genotypes in a choice test

\begin{tabular}{lccc}
\hline & \multicolumn{3}{c}{ Mean feeding damage index ${ }^{\mathrm{y}}$} \\
\cline { 2 - 4 } Genotypes & \multicolumn{1}{c}{10 days } & 20 days & 30 days \\
\hline Georgia Green & $0.25 \pm 0.06 \mathrm{~b}$ & $0.63 \pm 0.14 \mathrm{bc}$ & $0.87 \pm 0.19 \mathrm{bc}$ \\
Georgia Greener & $0.46 \pm 0.14 \mathrm{~b}$ & $0.98 \pm 0.22 \mathrm{ab}$ & $1.14 \pm 0.24 \mathrm{ab}$ \\
Georganic & $0.18 \pm 0.06 \mathrm{~b}$ & $0.36 \pm 0.06 \mathrm{c}$ & $0.40 \pm 0.06 \mathrm{c}$ \\
Tifguard & $0.13 \pm 0.03 \mathrm{~b}$ & $0.27 \pm 0.07 \mathrm{c}$ & $0.36 \pm 0.09 \mathrm{c}$ \\
Georgia-02C & $1.20 \pm 0.33 \mathrm{a}$ & $1.45 \pm 0.30 \mathrm{a}$ & $1.69 \pm 0.29 \mathrm{a}$ \\
Type III analysis & & & \\
$F$ & 10.24 & 10.59 & 12.71 \\
$P>F$ & $<0.0001$ & $<0.0001$ & $<0.0001$ \\
\hline
\end{tabular}

${ }^{y}$ Feeding damage rating at 10,20 , and 30 days after thrips release. Means with their standard errors in a column followed by the same letters are not significantly different from each other at $P=0.05$; data were analyzed by GLM procedure using repeated measures option in SAS.

${ }^{\mathrm{z}} F$ and $P>F$ values indicated differences in feeding damage on peanut genotypes resistant and susceptible to TSWV.

TABLE 6. Mean number of thrips on Tomato spotted wilt virus (TSWV)resistant and -susceptible peanut genotypes in a choice test

\begin{tabular}{lccc}
\hline & \multicolumn{3}{c}{ Mean thrips number ${ }^{\mathrm{y}}$} \\
\cline { 2 - 4 } Genotypes & \multicolumn{1}{c}{10 days } & 20 days & \multicolumn{1}{c}{30 days } \\
\hline Georgia Green & $15.00 \pm 4.71 \mathrm{a}$ & $12.30 \pm 1.61 \mathrm{ab}$ & $11.61 \pm 1.74 \mathrm{a}$ \\
Georgia Greener & $18.61 \pm 3.97 \mathrm{a}$ & $13.69 \pm 2.01 \mathrm{a}$ & $11.69 \pm 2.80 \mathrm{a}$ \\
Georganic & $8.46 \pm 2.34 \mathrm{~b}$ & $7.76 \pm 2.15 \mathrm{ab}$ & $5.53 \pm 1.53 \mathrm{~b}$ \\
Tifguard & $5.46 \pm 1.72 \mathrm{~b}$ & $6.30 \pm 1.87 \mathrm{~b}$ & $7.46 \pm 1.41 \mathrm{~b}$ \\
Georgia-02C & $20.92 \pm 5.38 \mathrm{a}$ & $13.00 \pm 1.80 \mathrm{a}$ & $17.15 \pm 2.80 \mathrm{a}$ \\
Type III analysis & & & \\
$F$ & 2.85 & 4.02 & 7.22 \\
$P>F$ & 0.0319 & $<0.0001$ & $<0.0001$ \\
\hline
\end{tabular}

y Thrips survival at 10,20 , and 30 days after release. Means with their standard errors in a column followed by the same letters are not significantly different from each other at $P=0.05$; data were analyzed by GLM procedure using repeated measures option in SAS.

${ }^{z} F$ and $P>F$ values indicated differences in thrips survival on peanut genotypes resistant and susceptible to TSWV.

TABLE 4. Summary of gene differentiation estimates along with their test statistics

\begin{tabular}{lcccccrrrrr}
\hline Comparison $^{\mathrm{w}}$ & $\mathrm{Hs}^{\mathrm{x}}$ & $\mathrm{Hst}^{\mathrm{x}}$ & $\chi^{2 \mathrm{y}}$ & $P^{\mathrm{y}}$ & $\mathrm{Kt}^{\mathrm{x}}$ & $\mathrm{Ks}^{\mathrm{x}}$ & $\mathrm{Kst}^{\mathrm{x}}$ & $\mathrm{Snn}^{\mathrm{x}}$ & $\mathrm{Fst}^{\mathrm{z}}$ \\
\hline N vs. O & 0.9875 & 0.0050 & 91.0000 & 0.1881 & 6.5152 & 1.8187 & 0.0393 & 0.9923 \\
R vs. S & 0.9913 & 0.0015 & 82.0000 & 0.2204 & 5.7931 & 5.8045 & -0.0019 & 0.8437 & -0.0080 \\
\hline
\end{tabular}

${ }^{\mathrm{w}}$ Comparison of isolates between population subgroups: $\mathrm{N}$ vs. $\mathrm{O}=$ new versus old and $\mathrm{R}$ vs. $\mathrm{S}=$ resistant versus susceptible.

${ }^{\mathrm{x}} \mathrm{Hs}$, Hst, Ks, Kst, and Snn were test statistics of genetic differentiation; Kst close to zero indicated no differentiation; Snn value close to 1 indicated differentiation.

${ }^{\text {y }}$ The $\chi^{2}$ and $P$ values were indicators of genetic differentiation between isolate subgroups; $P<0.05$ was considered significant.

${ }^{\mathrm{z}}$ Fst value between 0 and 1 indicated interpopulation diversity. 
Genotypes exhibiting field resistance have been grown in Georgia since $1997(12,15)$. The impact of these genotypes on the populations of TSWV had not been examined prior to our study. Presence of positive selection pressure, if any, could lead to the development of resistance-breaking strains. A number of studies have reported the presence of TSWV resistance-breaking strains in solanaceous crops $(36,43,51,52)$ and in engineered plants $(49)$. Development of resistance-breaking strains could reduce the usefulness of peanut genotypes exhibiting field resistance to TSWV. In this study, we addressed this issue by partially sequencing TSWV isolates from resistant and susceptible genotypes. Due to sequences in GenBank from the same location collected 12 years ago, we were able to compare the new sequences (generated in this study) with the old sequences. Maximum parsimony analysis followed by principal component analyses with nucleotide sequences did not indicate any consistent differences between the old and new isolates and between isolates from resistant and susceptible genotypes. The amino acid sequences indicated only one consistent substitution between old and new isolates.

In addition to high haplotype diversity and low nucleotide diversity, codon-based substitution models indicated an overabundance of $\mathrm{dN}$. When $\mathrm{dN}>\mathrm{dS}$, it was assumed that the selection in these codons was positive. We identified seven such codons, suggesting that positive selection could be influencing TSWV populations. However, the probability values associated with the test statistic $\mathrm{dN}-\mathrm{dS}$ were $>0.05$. This indicated that factors other than positive selection could be influencing the diversity in TSWV $N$ gene sequences. Earlier studies conducted with TSWV isolates also identified positive selection only at codon levels, and positive selection was not considered to be a major evolutionary factor in shaping the population structure of TSWV $(33,64)$. Although our results did not provide any evidence of positive selection pressure exerted by resistant peanut genotypes on TSWV over time, these results should be cautiously interpreted because only one gene was sequenced from these isolates. The logic behind choosing the TSWV $N$ gene for population structure analysis was that sequences of the same gene from TSWV isolates collected 12 years ago from the same location were available in GenBank. In addition to the $N$ gene, Tsompana et al. (64) and Kaye et al. (33) found evidence for positive selection at the amino acid level in other genes such as NSs, NSm, RdRp, and $\mathrm{G}_{\mathrm{N}} / \mathrm{G}_{\mathrm{C}}$ of TSWV.

Tajima's test of neutrality (59) and Fu and Li's test statistics (21) were negative, indicating that purifying selection or population expansion could be influencing the population structure of TSWV rather than positive selection pressure exerted by TSWVresistant genotypes. Fu's F test (20), which assumes an infinite sites model of mutation, is a more robust test to identify the

TABLE 7. Feeding damage induced by thrips on Tomato spotted wilt virus (TSWV)-resistant and -susceptible peanut genotypes in a no-choice test

\begin{tabular}{llll}
\hline & \multicolumn{3}{c}{ Mean feeding damage index } \\
\cline { 2 - 4 } Genotypes & \multicolumn{1}{c}{10 days } & \multicolumn{1}{c}{20 days } & 30 days \\
\hline Georgia Green & $0.72 \pm 0.13 \mathrm{ab}$ & $1.80 \pm 0.24 \mathrm{~b}$ & $2.24 \pm 0.26 \mathrm{a}$ \\
Georgia Greener & $0.71 \pm 0.16 \mathrm{ab}$ & $1.80 \pm 0.28 \mathrm{~b}$ & $2.17 \pm 0.28 \mathrm{a}$ \\
Georganic & $0.32 \pm 0.11 \mathrm{~b}$ & $0.83 \pm 0.16 \mathrm{c}$ & $1.08 \pm 0.23 \mathrm{~b}$ \\
Tifguard & $0.30 \pm 0.09 \mathrm{~b}$ & $0.95 \pm 0.19 \mathrm{c}$ & $1.00 \pm 0.17 \mathrm{~b}$ \\
Georgia-02C & $1.22 \pm 0.23 \mathrm{a}$ & $2.45 \pm 0.22 \mathrm{a}$ & $2.74 \pm 0.16 \mathrm{a}$ \\
Type III analysis & & & \\
$F$ & 6.48 & 17.39 & 18.51 \\
$P>F$ & 0.0002 & $<0.0001$ & $<0.0001$ \\
\hline
\end{tabular}

${ }^{\mathrm{y}}$ Feeding damage rating at 10, 20, and 30 days after thrips release. Means with their standard errors in a column followed by the same letters are not significantly different from each other at $P=0.05$; data were analyzed by GLM procedure using repeated measures option in SAS.

${ }^{\mathrm{z}} F$ and $P>F$ values indicated differences in feeding damage on peanut genotypes resistant and susceptible to TSWV. presence of population expansion than Tajima's D. A negative value, as observed in our case, confirmed the presence of population expansion. Hudson's haplotype diversity and supporting test statistics (29) provided no evidence of population differentiation among subgroups. However, Hudson's nucleotide based statistics ( $\mathrm{K}$ and Kst) (29) indicated population differentiation between old and new isolates. Hudson's powerful Snn (28), which is independent of sample size and diversity, also identified population differentiation between old and new isolates (a value close to 1). No such effects were observed between TSWV isolates obtained from resistant and susceptible genotypes. Hudson's Fst (31), also a measure of population differentiation, confirmed differentiation between old and new isolates but not between isolates from resistant and susceptible genotypes. Thus, purifying selection, population expansion, and population differentiation seem to have shaped the population structure of TSWV in Georgia rather than positive selection. Moreover, these effects seem to be influenced temporally. These results mirror the findings of Tsompana et al. (64) and Kaye et al. (33). They also suggested that the population structure of TSWV was influenced by purifying selection and population differentiation rather than positive selection. This could be due to the lack of high levels of TSWV resistance in peanut and also due to the availability of numerous other susceptible hosts in the landscape. TSWV has a very broad host range, with $>1,000$ host species $(47,65)$. Additionally, our results showed evidence of recombination events. The number of recombination events was more in new isolates and isolates from TSWV-resistant plants rather than old isolates and isolates from susceptible plants. This bias could merely be due to the reduced sample sizes in the case of old isolates and isolates from susceptible genotypes compared with new isolates and isolates from resistant genotypes. Tsompana et al. (64) also identified recombination events in their isolates but did not consider them to be a major factor shaping the population structure of TSWV.

In addition to resistance to the virus, resistance against the vector could be critical for the management of TSWV in peanut. Resistance against thrips has been identified in solanaceous crops such as pepper that resulted in reduced virus transmission $(41,42)$. Maris et al. (42) found reduced thrips preference, oviposition rate, and reproduction on thrips-resistant pepper compared with susceptible pepper. They also found that the resistant plants were less preferred by thrips than susceptible plants, which resulted in quick dispersion and reduced reproduction. Thus far, there has been no detailed screening of the peanut genotypes against thrips under laboratory or greenhouse conditions, because it was widely assumed that the genotypes only exhibited resistance to the virus and not the vector $(13,17,18)$. However, both choice tests and nochoice tests conducted in the greenhouse revealed differential

TABLE 8. Mean number of thrips on Tomato spotted wilt virus (TSWV)resistant and -susceptible peanut genotypes in a no-choice test

\begin{tabular}{llcl}
\hline & \multicolumn{3}{c}{ Mean thrips number ${ }^{\mathrm{y}}$} \\
\cline { 2 - 4 } Genotypes & \multicolumn{1}{c}{10 days } & \multicolumn{1}{c}{20 days } & \multicolumn{1}{c}{30 days } \\
\hline Georgia Green & $6.80 \pm 1.99 \mathrm{ab}$ & $11.93 \pm 1.34 \mathrm{a}$ & $7.67 \pm 1.47 \mathrm{a}$ \\
Georgia Greener & $7.47 \pm 1.78 \mathrm{ab}$ & $7.00 \pm 1.18 \mathrm{bc}$ & $5.27 \pm 0.89 \mathrm{ab}$ \\
Georganic & $4.53 \pm 0.61 \mathrm{~b}$ & $4.40 \pm 0.72 \mathrm{c}$ & $4.27 \pm 1.36 \mathrm{ab}$ \\
Tifguard & $3.27 \pm 0.42 \mathrm{~b}$ & $5.07 \pm 0.48 \mathrm{c}$ & $3.60 \pm 0.75 \mathrm{~b}$ \\
Georgia-02C & $9.53 \pm 2.46 \mathrm{a}$ & $10.13 \pm 2.62 \mathrm{a}$ & $5.40 \pm 1.39 \mathrm{ab}$ \\
Type III analysis & & & \\
$F$ & 3.45 & 9.84 & 2.68 \\
$P>F$ & 0.0126 & $<0.0001$ & 0.0390 \\
\hline
\end{tabular}

y Thrips survival at 10, 20, and 30 days after release. Means with their standard errors in a column followed by the same letters are not significantly different from each other at $P=0.05$; data were analyzed by GLM procedure using repeated measures option in SAS.

${ }^{\mathrm{z}} F$ and $P>F$ values indicated differences in thrips survival on peanut genotypes resistant and susceptible to TSWV. 
feeding responses. In both cases, reduced feeding damage was observed in Georganic and Tifguard when compared with other genotypes. It is not clear as to what influenced this difference. An earlier study indicated that differences in the color of peanut foliage could affect thrips preferences and, consequently, feeding on them (1). Tifguard's foliage color, at least to the human eye, is not very different from other genotypes that sustained greater levels of feeding damage. However, Navia Gine (46) reported differences in reflectance, measured as normalized difference vegetation index, between Tifguard and Georgia-06G. In addition, in choice and no-choice tests, we consistently found fewer adults and larvae on Tifguard than on other genotypes. In a different study, we also found reduced developmental time on Tifguard when compared with other second-generation TSWV-resistant genotypes (55). Tifguard possesses resistance against root-knot nematode Meloidogyne arenaria (Neal) Chitwood race 1 (26). It is not clear whether nematode resistance could influence thrips feeding and survival. More research needs to be conducted to evaluate the potential of cross-resistance between nematodes and thrips.

In conclusion, second-generation TSWV-resistant peanut genotypes exhibited systemic infection upon inoculation with TSWV. The relative numbers of viral copies was similar between resistant and susceptible genotypes. Neutrality tests indicated that purifying selection, population expansion, and population differentiation other than positive selection influenced the population structure of TSWV more than positive selection. These results suggested that the levels of resistance in these genotypes might not exert substantial levels of selection pressure on the virus itself. On the contrary, differential feeding responses and survival on some genotypes suggested that the resistance observed in the field could be not only a reaction to the effects of the virus on the host plant but also due to the interactions between thrips and peanut genotypes. Perhaps this could also explain why thrips-mediated transmission resulted in reduced virus infection and virus accumulation in second-generation TSWV-resistant peanut genotypes (55). In contrast, the observed difference in some, if not all, genotypes could merely be due to loads of virus delivered through each inoculation method. More research needs to be conducted to explore this phenomenon.

\section{ACKNOWLEDGMENTS}

This research was supported by funds from Georgia Peanut Commission, National Peanut Board, and Southern Region IPM, United States Department of Agriculture NIFA. We thank S. McKeown, S. Thompson, and S. Diffie for their the technical assistance; and V. Koundal for providing useful tips on phylogenetic analyses.

\section{LITERATURE CITED}

1. Amin, P. W. 1985. Apparent resistance of groundnut cultivar Robut 33-1 to bud necrosis disease. Plant Dis. 69:718-719.

2. Angelella, G., and Riley, D. G. 2010. Effects of pine pollen supplementation in an onion diet on Frankliniella fusca reproduction. Environ. Entomol. 39:505-512.

3. Black, L. L., Hobbs, H. A., and Gatti, J. M. 1991. Tomato spotted wilt virus resistance in Capsicum chinense PI 152225 and 159236. Plant Dis. $75: 863$.

4. Black, L. L., Hobbs, H. A., and Kammerlohr, D. S. 1996. Resistance of Capsicum chinense lines to Tomato spotted wilt virus isolates from Lousiana, USA, and inheritance of resistance. Acta Hortic. 431:393-401.

5. Boiteux, L. S., and de Avila, A. C. 1994. Inheritance of a resistance specific to Tomato spotted wilt tospovirus in Capsicum chinese 'PI 159236'. Euphytica 75:139-142.

6. Branch, W. D. 1994. Registration of 'Georgia Browne' Peanut. Crop Sci. 34:1125-1126.

7. Branch, W. D. 1996. Registration of 'Georgia Green' Peanut. Crop Sci. 36:806.

8. Branch, W. D. 2003. Registration of 'Georgia-02C' peanut. Crop Sci. 43:1883-1884.
9. Branch, W. D. 2007. Registration of 'Georgia-06G' Peanut. J. Plant Reg. 1:120-120.

10. Branch, W. D. 2007. Registration of 'Georgia Greener' peanut. J. Plant Reg. 1:121.

11. Branch, W. D., and Culbreath, A. K. 2011. Registration of 'Georgia-10T' peanut. J. Plant Reg. 5:279-281.

12. Culbreath, A. K., and Srinivasan, R. 2011. Epidemiology of spotted wilt disease of peanut caused by Tomato spotted wilt virus in the southeastern U. S. Virus Res. 159:101-109.

13. Culbreath, A. K., Tillman, B. L., Gorbet, D. W., Holbrook, C. C., and Nischwitz, C. 2008. Response of new field-resistant peanut cultivars to twin-row pattern or in-furrow applications of phorate for management of spotted wilt. Plant Dis. 92:1307-1312.

14. Culbreath, A. K., Todd, J. W., Branch, W. D., Brown, S. L., Demski, J. W., and Beasley, J. P., Jr. 1994. Effect of new peanut cultivar Georgia Browne on epidemics of spotted wilt. Plant Dis. 78:1185-1189.

15. Culbreath, A. K., Todd, J. W., and Brown, S. L. 2003. Epidemiology and management of Tomato spotted wilt in peanut. Annu. Rev. Phytopathol. 41:53-75.

16. Culbreath, A. K., Todd, J. W., Demski, J. W., and Chamberlin, J. R. 1992. Disease progress of spotted wilt in peanut cultivars Florunner and Southern Runner. Phytopathology 82:766-771.

17. Culbreath, A. K., Todd, J. W., Gorbet, D. W., Branch, W. D., Holbrook, C. C., Shokes, F. M., and Demski, J. W. 1996. Variation in susceptibility to Tomato spotted wilt virus among advanced breeding lines of peanut (Arachis hypogaea). Acta Hortic. 431:402-410.

18. Culbreath, A. K., Todd, J. W., Gorbet, D. W., Branch, W. D., Sprenkel, R. K., Shokes, F. M., and Demski, J. W. 1996. Disease progress of Tomato spotted wilt virus in selected peanut cultivars and advanced breeding lines. Plant Dis. 80:70-73.

19. Culbreath, A. K., Todd, J. W., Gorbert, D. W., Shokes, F. M., and Pappu, H. R. 1997. Field response of new peanut cultivar UF 91108 to Tomato spotted wilt virus. Plant Dis. 81:1410-1415.

20. Fu, Y. 1997. Statistical tests of neutrality of mutations against population growth, hitchhiking and background selection. Genetics 147:915-925.

21. Fu, Y., and Li, W. H. 1993. Statistical tests of neutrality of mutations. Genetics 133:693-709.

22. Garcia, L. E., Brandenburg, R. L., and Bailey, J. E. 2000. Incidence of Tomato spotted wilt virus (Bunyaviridae) and tobacco thrips in Virginiatype peanuts in North Carolina. Plant Dis. 84:459-464.

23. Gorbet, D. W., Norden, A. J., Shokes, F. M., and Knauft, D. A. 1987. Registration of 'Southern Runner' peanut. Crop. Sci. 27:817.

24. Hall, B. G. 2001. Phylogenetic Trees Made Easy. Sinauer Associates, Sunderland, MA.

25. Holbrook, C. C., and Culbreath, A. K. 2008. Registration of 'Georganic' Peanut. J. Plant Reg. 2:17

26. Holbrook, C. C., Timper, P., Culbreath, A. K., and Kvien, C. 2008. Registration of 'Tifguard' peanut. J. Plant Reg. 2:92-94.

27. Hudson, R. R. 1987. Estimating the recombination parameter of a finite population model without selection. Genet. Res. 50:245-250.

28. Hudson, R. R. 2000. A new statistic for detecting genetic differentiation. Genetics 155:2011-2014.

29. Hudson, R. R., Boos, D. D., and Kaplan, N. L. 1992. A statistical test for detecting geographic subdivision. Mol. Biol. 9:138-151.

30. Hudson, R. R., and Kaplan, N. L. 1985. Statistical properties of the number of recombination events in the history of a sample of DNA sequences. Genetics 111:147-164.

31. Hudson, R. R., Slatkin, M., and Maddison, W. P. 1992. Estimations of levels of gene flow from DNA sequence data. Genetics 132:583-589.

32. Jain, R. K., Pappu, S. S., Pappu, H. R., Culbreath, A. K., and Todd, J. W. 1998. Molecular diagnosis of tomato spotted wilt tospovirus infection of peanut and other field and greenhouse crops. Plant Dis. 82:900-904.

33. Kaye, A. C., Moyer, J. W., Parks, E. J., Carbone, I., and Cubeta, M. A. 2011. Population genetic analysis of Tomato spotted wilt virus on peanut in North Carolina and Virginia. Phytopathology 101:147-153.

34. Kosakovsky Pond, S. L., Frost, S. D. W., and Muse. S. V. 2005. HyPhy: Hypothesis testing using phylogenies. Bioinformatics 21:676-679.

35. Krishna Kumar, N. K., Ullman, D. E., and Cho, J. J. 1993. Evaluation of Lycopersicon germplasm for tomato spotted wilt tospovirus resistance by mechanical and thrips transmission. Plant Dis. 77:938-941.

36. Latham, L. J., and Jones, R. A. C. 1998. Selection of resistance breaking strains of tomato spotted wilt tospovirus. Ann. Appl. Biol. 133:385-402.

37. Librado, P., and Rozas, J. 2009. DnaSP V5: A software for comprehensive analysis of DNA polymorphism data. Bioinformatics 25:1451-1452.

38. Maddison, W. P., and D. R. Maddison. 2011. Mesquite: A Modular System for Evolutionary Analysis, Version 2.75. http://mesquiteproject.org

39. Mandal, B., Csinos, A. S., Martinez-Ochoa, N., and Pappu, H. R. 2008. A rapid and efficient inoculation method for Tomato spotted wilt tospovirus. J. Virol. Methods 149:195-198. 
40. Mandal, B., Pappu, H. R., Culbreath, A. K., Holbrook, C. C., Gorbet, D. W., and Todd, J. W. 2002. Differential response of selected peanut (Arachis hypogaea) genotypes to mechanical inoculation by Tomato spotted wilt virus. Plant Dis. 86:939-944.

41. Maris, P. C., Joosten, N. N., Goldbach, R. W., and Peters, D. 2003. Restricted spread of Tomato spotted wilt virus in thrips-resistant pepper. Phytopathology 93:1223-1227.

42. Maris, P. C., Joosten, N. N., Peters, D., and Goldbach, R. W. 2003. Thrips resistance in pepper and its consequences for the acquisition and inoculation of Tomato spotted wilt virus by the western flower thrips. Phytopathology 93:96-101.

43. Moury, B., Palloix, A., Selassie, K. G., and Marchoux, G. 1997. Hypersensitive resistance to Tomato spotted wilt virus in three Capsicum chinense accessions is controlled by single gene and overcome by virulent strains. Euphytica 94:45-52.

44. Munger, F. 1942. A method for rearing citrus thrips in the laboratory. J. Econ. Entomol. 35:373-375.

45. Muse, S. V., and Gaut, B. S. 1994. A likelihood approach for comparing synonymous and non-synonymous nucleotide substitution rates, with application to the chloroplast genome. Mol. Biol. Evol. 11:715-724.

46. Navia Gine, P. A. 2012. Characterization of the relationship between leaf spot severity and yield in new peanut runner-type cultivars and effects of new peanut genotypes on leaf spot epidemics. M.S. thesis, Department of Plant Pathology, University of Georgia, Athens.

47. Pappu, H. R., Jones, R. A. C., and Jain, R. K. 2009. Global status of Tospovirus epidemics in diverse cropping systems: Successes achieved and challenges ahead. Virus Res. 141:219-236.

48. Pappu, H., Pappu, S., Jain, R., Bertrand, P., Culbreath, A., McPherson, R., and Csinos, A. 1998. Sequence characteristics of natural populations of tomato spotted wilt Tospovirus infecting flue-cured tobacco in Georgia. Virus Genes 17:169-177.

49. Qiu, W. P., and Moyer, J. W. 1999. Tomato spotted wilt tospovirus adapts to the TSWV $N$ gene-derived resistance by genome reassortment. Phytopathology 89:575-582.

50. Riley, D. G., Joseph, S. V., Srinivasan, R., and Diffie, S. 2011. Thrips vectors of tospoviruses. J. Integr. Pest Mange. I1-I10.

51. Roggero, P., Masenga, V., and Tavella, L. 2002. Field isolates of Tomato spotted wilt virus overcoming resistance in pepper and their spread to other hosts in Italy. Plant Dis. 86:950-954.

52. Roggero, P., Melani, V., Ciuffo, M., Tavella, L., Tedeschi, R., and Stravato, V. M. 1999. Two field isolates of tomato spotted wilt tospovirus overcome the hypersensitive response of a pepper (Capsicum annuиm) hybrid with resistance introgressed from $C$. chinense PI152225. Plant Dis. 83:965.

53. Rosello, S., Diez, M. J., and Nuez, F. 1998. Genetics of Tomato spotted wilt virus resistance coming from Lycopersicon peruvianum. Eur. J. Plant Pathol. 104:499-509.

54. Rotenberg, D., Kumar, N. K. K., Ullman, D. E., Montero-Astúa, M., Willis, D. K., German, T. L., and Whitfield, A. E. 2009. Variation in Tomato spotted wilt virus titer in Frankliniella occidentalis and its association with frequency of transmission. Phytopathology 99:404-410.

55. Shrestha, A., Srinivasan, R., Sundaraj, S., Culbreath, A., and Riley, D. 2013. Second generation peanut genotypes resistant to thrips-transmitted Tomato spotted wilt virus exhibit tolerance rather than true resistance and differentially affect thrips fitness. J. Econ. Entomol. 106:587-596.

56. Smith, O. D., Simpson, C. E., Black, M. C., and Besler, B. A. 1998. Registration of Tamrun 98 peanut. Crop Sci. 38:1403.

57. Stevens, M. R., Scott, S. J., and Gergerich, R. C. 1991. Inheritance of a gene for resistance to Tomato spotted wilt virus TSWV from Lycopersicon peruvianum Mill. Euphytica 59:9-17.

58. Swofford, D. L. 2003. PAUP*. Phylogenetic Analysis using Parsimony (*and Other Methods), Version 4. Sinauer Associates, Sunderland, MA.

59. Tajima, F. 1989. Statistical method for testing the neutral mutation hypothesis by DNA polymorphism. Genetics 123:585-595.

60. Tamura, K., and Nei, M. 1993. Estimation of the number of nucleotide substitutions in the control region of mitochondrial DNA in humans and chimpanzees. Mol. Biol. Evol. 10:512-526.

61. Tamura, K., Peterson, D., Peterson, N., Stecher, G., Nei, M., and Kumar, S. 2011. MEGA5: Molecular evolutionary genetics analysis using maximum likelihood, evolutionary distance, and maximum parsimony methods. Mol. Biol. Evol. 28:2731-2739.

62. Todd, J. W., and Culbreath, A. K. 1995. Thrips populations and spotted wilt disease progress on resistance/susceptible cultivars treated with various insecticides. (Abstr.) Proc. Am. Peanut Res. Educ. Soc. 27:35.

63. Todd, J. W., Culbreath, A. K., and Brown, S. L. 1996. Dynamics of vector populations and progress of spotted wilt disease relative to insecticide use in peanuts. Acta Hortic. 431:483-490.

64. Tsompana, M., Abad, J., Purugganan, M., and Moyer, J. W. 2005. The molecular population genetics of the Tomato spotted wilt virus (TSWV) genome. Mol. Ecol. 14:53-66.

65. Whitfield, A. E., Ullman, D. E., and German, T. L. 2005. Tospovirusthrips interactions. Annu. Rev. Phytopathol. 43:459-489. 